\title{
Role of Digital Nomad in Supporting Tourism in Indonesia: Case Study Bali
}

\author{
Roby Rakhmadi ${ }^{1, *}$ \\ 1, International Relations Department, Universitas Lampung \\ *Corresponding author. Email: roby.rakhmadi007@fisip.unila.ac.id
}

\begin{abstract}
Tourism is an essential sector in Indonesia development which increase significantly in last years. It creates many opportunities for other fields to grow. Tourism can be one of the factors contribute for Indonesia wellfare. The advent of digital nomad which came from foreign countries can enforce the tourism sector in Indonesia especially Bali. The pattern in which tourist came and work virtually from the place they visited can be replicated in another province than Bali. So they travel along with the digitalization of their work to contribute in Indonesia economy indirectly.
\end{abstract}

Keywords: Tourism, Digital Nomad, Digitalization.

\section{INTRODUCTION}

Global tourism has grown dramatically over the last decade, and tourism has become one of the world's fastest expanding industries. International tourist arrivals climbed by $7 \%$ in 2017 , reaching over 1.32 billion, an increase of 84 million over 2016. Tourism has also become a catalyst for global economic development by increasing the country's national GDP, hence producing job opportunities and income for citizens. According to UNWTO Highlights, tourism generated 1.6 trillion US dollars in 2017. [1]

Indonesia's tourism industry has grown dramatically as the number of international tourists visiting the country reached 14.04 million, an increase of 21.44 percent over the previous year. The number of international tourists continued to grow in 2018 and now stands at 15.81 million. In 2016, tourism generated a national revenue of 13.5 billion US dollars. National revenue from tourism came in second place, after crude palm oil (CPO), at US\$ 15.9 billion. In 2017, faktanews mentioned that the country earned US\$ 16,8 billion from tourism. [2] Tourism has been the primary sector of the Bali economy since a long time and able to stimulate other sectors. According to Trip Advisor, popularity of tourism in Bali has been surpassing London (second rank) and Paris (third rank) in 2017 as the world's most famous tourist destination. [3] In 2017 Bureau of Tourism Bali Province stated there are $5,697,739$ foreign tourists came directly in Bali. [4]. In
2018 alone, a total of 6,070,473 tourists visited Bali, an increase of 6.54 percent from 2017. [5] Foreign visitors to Bali accounted for 38.4 percent of all foreign visitors to Indonesia in 2018.

The development of digital technology and information is critical to the global tourist industry's growth. The internet-based digital communication technology is frequently used for tourism development, particularly for tourism marketing, including promotion and transaction for tourism businesses. [6] [7] The advancement of digital communication technology via the internet has altered the marketing of transaction cycles that take place primarily between tourists and the tourism industry (business to customer) without the intervention of a middleman (travel agent) [8].

Not has the development of digital technology-aided and accelerated the provision of services to tourists, but it has also increased the accountability of service providers. Tourists can use digital technology to be effective and productive while visiting a tourist object. The internet may generate several career opportunities by forming varieties of freelancers such as writers, data entry operators, designers, and programmers. Additionally, long-distance work via the internet has altered the perspective of today's youth. They do not believe that a regular job is necessary, as freelance work can provide enough revenue to sustain their everyday lives. This type of scenario gets more prevalent due to 
the presence of tourists who are self-employed. These individuals are referred to as digital nomads.

The phrase "digital nomad" refers to those who do not dwell in one area for an extended period of time and work remotely via the internet. [9] These digital workers work in a variety of business areas utilizing only their smartphones and laptops. They must supply their own internet connection in order to perform their duties. These digital nomads can work from their hotels or apartments. Several of them, however, choose to work at coffee shops or restaurants, where they may enjoy the cuisine and landscape. That is one of reasons stourist destinations in Bali are densely packed with young people worldwide looking for restaurants and coworking spaces with free Wi-Fi.

Novriandi mentioned there are advantages of working as a digital nomad: [10] (i) Self-contained site,(ii) Ease of establishing a productive $\operatorname{mood}($ iii) Unlimited Creativity; (iv) Flexible work hours and assistance for coworking spaces. The development results in the birth of a new tourism model called as Digital Nomads Tourism which merges both activities of digital nomads and tourism. According to Makimoto digital nomads are persons who do not require a fixed workspace or particular rooms to work; all they want is a high-speed internet connection to support them in their work. [11] Although their numbers are impossible to predict, they can reach 4.8 million in the United States. [12] Numerous experts forecast that the number of digital nomads will exceed 1 billion by 2035. [13] Ubud and Canggu are two of the most popular destinations for digital nomads worldwide [14]. Although digital nomad size and impact to local economies are currently modest, the tourism business targeting digital nomads is a new market potential that can not be ignored.

\section{METHOD}

This paper use a qualitative approach and literature study to get the final result. Literature study help analyze of the issue under investigation, analytical philosophical support, and information for research debate. [15]

This paper use descriptive method to get result of research. The source of data is conducted from a variety of publications, books, and authoritative news outlets in internet. This study was held from July-September 2021. It is hoped that this paper can become the basis for further research, both empirically, descriptively, and conceptually.

\section{RESULT AND ANALYSIS}

\subsection{Nomadic Tourism}

Nomadic tourism is a new style of tourism where visitors can stay in a tourist destination with secure and portable facilities within a certain period of time. In addition, nomadic tourism is a tourism activity carried out by tourists of a productive age between 35 and 55 years old, who have income and rely on the latest information. [16]

Through the Ministry of Tourism, Indonesia has launched a nomadic destination and tourism digitization program in 2018 as a quick effort to attract tourists. [17]

Development of the nomadic tourism ecosystem in Indonesia is divided into three types of nomadic tourists with the category of backpacker tourists. Backpacker tourists are identified as tourists who only rely on carrying a bagpack on each trip.But in nomadic tourism, the category of backpackers is very useful for the destination because this group of tourists uses digital technology on every trip. According Budiasa [18], there are three types of nomadic tourists, which is described as follows

(a) Glampacker, or referred to as a tourist in the category of' millennial nomad.These travelers are wandering around to see the' instagrammable' tourist spot worldwide, or tourists who take advantage of digitization to document travel moments in the Instagram and Facebook media. There are a total of 27 million people who have an affinity with Indonesia and are interested in backpacking, camping and nomadic tourism.

b) Luxpackers or tourists in the "luxurious nomadic" category; where these tourists wander around to forget the environment of their home regions by using online media facilities. There are 7.7 million tourists in this luxury packer category who are using certain travel booking facilities such as Conde Nest travel media, Expedia, booking.com, AirBnB, hotels.com, and Agoda.com.

c) Flashpacker, or digital nomad tourists, who stay temporarily in a place while working from anywhere. There are 5 million tourists in the flashpacker category who have an affinity to Indonesia and are interested in the nomadic digital world.In this category, the Canggu area in the North Kuta sub-district of Badung RegencyBali won the title of "number 1 most popular digital nomadic in the world." Canggu was chosen with the title because it fulfills the requirements of providing tourists with peace of mind and facility of good internet access. Nomadic tourism in developing tourist destinations is divided into 3 parts, which are [19]:

(a) Nomadic Tourist Attraction is a form of attraction that provides entertainment or events for nomadic tourists. Entertainment attractions can be made from a variety of natural, artificial and event attractions. Examples of attractions in the form of events packed every month by the Badung regency to attract tourists to the destination. 
(b) Nomadic Tourism Amenities (facilities required by nomadic tourists) provide accommodation in the form of a caravan, glamping, or home pod.

(1) Caravan can be moved whenever and placed in beautiful areas of tourist destinations.

(2) Glamping, which is a lodging facility in the form of a luxury tent with star hotel facilities, where the tourist is exposed to nature experience with luxurious service facilities.

(3) Home-pod is an accommodation facility in the form of egg-houses. This form is heavier and structurally stable than glamping, thus the length of stay in the home-pod can be longer than in glamping. In the North Badung (Plaga) area with more space and spacious land facilities, the nomadic facility category can be prepared.Nomadic facilities can also be set up in coastal areas for nomadic tourists who want maximum digital access with a beach view.

(c) Nomadic Tourism Access is the convenience of nomadic tourists traveling to their destination faster, such as using airplanes, ships, or helicopters. In the telecommunications access category; the Canggu, Badung area has been mentioned as a favorite destination as a nomadic digital destination with accessible Wi-Fi.

\subsection{Bali as Hub of Nomadic Tourism}

To maintain sustainable tourism, it is necessary to maintain visitor satisfaction, ensure positive experience, and raise tourist awareness [20]about tourism sustainability. [21] To ensure tourist satisfaction while accommodating the digital nomads tourist market, several factors such as the digital nomads tourist's characteristics, perception, and satisfaction with the Bali tourist destination must become requirements in order for them to choose Bali as their preferred tourist destination.

According to the foregoing, digital nomads have the potential to be a future part of Bali tourism, however no research on digital nomads tourism has been conducted in Bali or Indonesia.

Digital nomads are visitors who visit Bali in addition to enjoying the attractions and working without regard for space or time constraints and who are constantly on the go (nomads). Online business potential driven by the rapid advancement of information and communication technology, both in hardware and software. Famous coworking spaces in Bali include Hubud in Ubud (founded by Steve Munroe, Peter Wall, and John Alderson), Dojo Bali in Canggu (founded by Michael Craig), Outpost Canggu in Canggu (founded by David Abraham and Bryan Stewart), and Sanur Creative Hub in Sanur (founded by Alm. Arif "Ayip" Budiman). All of those locations were controlled by non-community members of Sanur, particularly Intaran village, but the majority were foreigners.
The possibility of establishing a new tourist attraction, called Digital Nomads Tourism, is achievable due to the tourism amenities given. These coworking spaces offer amenities such as high-speed internet, an excellent indoor and outdoor environment, meeting rooms, coaching rooms, a digital membership card, SuperPass access via phone (barcode scanning), mail address, storage lockers, and a Skype Booth. Additionally, they provide a variety of membership rates (daily, monthly, three monthlies, and hourly).

The benefits of a digital nomad lifestyle include independence from a fixed location, ease of getting in the mood to work, boundless creativity, flexible working hours, and support for coworking spaces.

Several qualities of digital nomads lead them to pick Bali as a destination, particularly Ubud and Canggu. Provide coworking and co-living space (accommodation). Consider individual circumstances, such as:

- The weather, owing to Bali's pleasant climate o Convenient access to tourist destinations o A diverse range of tourist attractions, including nature, cultural heritage, and hospitality

- Amenities encourage visitors to stay longer in a particular tourist region, such as lodging, food, and beverages.

- Involvement of tourism institutions that support tourist sites, such as security measures that provide travelers with comfort

- Environmental stewardship o Travel bureau, advertising, and marketing services

- Numerous unusual and non-existent events in their country of origin o Corporate incentives o Visit friends and relatives

- Present (Souvenir)

- Reasonably priced items.

- A lower cost of living o A more polite and welcoming community

\subsection{Factors of Nomad Tourism}

There are three factors that support the development of community-based digital nomad tourism: the entrepreneurial soul factor in the digital world, digital business nomad tourism factor as a new business alternative, and ease of business. Mental attitude, leadership, skills, enthusiasm, creativity and courage to take risks are some of the characteristics that entrepreneurs should have.[22]

The development of digital nomad tourism is influenced by three elements, such as digital nomad, online business, and entrepreneur in managing the business. A model can be drawn for a community-based development of digital nomad tourism are shown in 


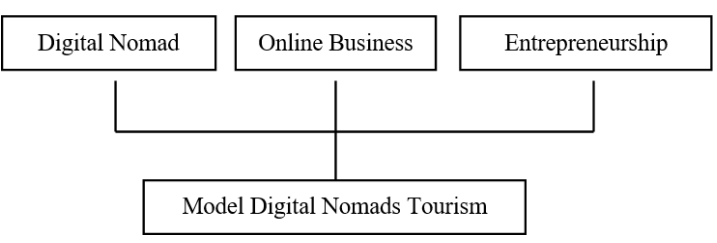

Fig. 1. A model of community-based development in digital nomad tourism.

The opportunity in developing coworking space is becoming a new potential business in tourism sector. The coworking space has been evolving since 2013 and grow rapidly with very potential market segment, even though due to the Covid19 pandemic causes challenges to their operational. By seeing the development of information and communication technology, this business will be more developed.

The young generation that dominates the Indonesian population has a potential market segment with the highest loading factor value with a percentage of variance for that factor is $21.169 \%$, but still dominated by the ecclesiastical and not community based. Economic turnover will occur bigger in the village if management is done by local community (who lives in the location of this business). Moreover, it is managed by a cooperative based on family and cooperation.

Many businesses have begun to think of a place of business that requires a considerable investment beside the operating costs and maintenance required when setting up a place of business. On the other hand, it will provide the existing efforts to diversify its efforts into more promising efforts and future developments to grow rapidly. Coworking space should be able to accommodate the needs of workers such as comfortable space, office furniture, food and beverage facilities, and of course WIFI and other equipment

\subsection{Destination Of Nomadic Tourism In Bali}

\subsubsection{Ubud}

Foreign tourists are drawn to Ubud by the strength of art and culture in the community's daily life, which has helped foreign tourists feel at ease living in a characteristically Balinese town. [23] The natural beauty of the Ubud area has also attracted foreign tourists to extend their stay. Rice field terraces may also be visible in the Ubud area, facilitated by the surrounding green area, which enhances the rural atmosphere's charm. Ecotourism is particularly prevalent in the Ubud area, specifically the Monkey Forest, which attracts tourists.

Additionally, Ubud have a white water rafting experiences, a castle, a market, and numerous galleries, paintings, and museums. Additionally, Ubud is wellknown as an artistic hotspot. Every night, traditional dance performances are presented in certain locations, which helps create a more exciting ambiance in the evening and attracts tourists who enjoy their time. Since the 1930s, the Ubud area has been popular with Western tourists. Walter Spies, a German painter, and Rudolf Bonnet, a Dutch painter, used to live in Ubud. They were welcomed by Cokorda Gede Agung Sukawati, a member of the Puri Agung Ubud community. Their painting collection is currently on display at the Puri Lukisan Museum.

\subsubsection{Hubud}

Hubud is a neighborhood in Ubud where digital nomads congregate and share workspaces similar to offices. Hubud provides high-speed internet access and a work environment that is conducive to collaborative work in small groups. It features beautiful rice field views as well as a fully air-conditioned meeting room equipped with an LCD projector and whiteboard. Hubud provides access to the Hubud online community, the $\mathrm{H}$ pass discount card, a storage locker, a Skype room, and a canteen for digital nomads. Hubud serves as a coworking space, as well as a co-living and co-giving space. Hubud, as a co-living space, also provides housing and other amenities.

Hubud[23] also serves as a co-learning environment, hosting various programs aimed at expanding knowledge, facilitating professional advancement, and obtaining experience. It gives co-giving opportunities that mix social service and entrepreneurship to support Ubud's small businesses.

Co-giving programs enhance both business and community connection. Members of Hubud contribute to the co-giving program, which benefits the local community. Additionally, this program encourages members to develop new skills and information. Hubud has developed into a hub for the digital nomad community. They will earn friendship and experience in Ubud as a result of the connections they make. Hubud is also a hub for collaboration in the creative business sector.

\subsubsection{Canggu}

Canggu is a beach town in southern Bali surrounded by rice paddies. There are several well-known beaches in Canggu such as Canggu beach and Echo beach, which have excellent waves for surfers worldwide. Canggu has numerous excellent lodgings, ranging from star hotels to villas, non-star hotels, and homestays. Canggu is adjacent to Seminyak, which is known for its opulent shops and restaurants. Popularity of Canggu has grown in as a result of the growth of tourism in Kuta 
beach, Legian, and Seminyak. Many former residents of Kuta, Legian, and Seminyak now prefer to live in Canggu. They reasoned that prices in Kuta, Legian, and Seminyak were increasing recently. Canggu gained popularity as a result of the expatriates who influenced the development of the area. As a result, Canggu has grown swiftly and developed into a popular coastal tourist destination that retains a rural atmosphere compared to Kuta, Legian, and Seminyak.

\subsubsection{Collaboration Between Dojo and Bali}

Collaboration between Dojo and Bali in Canggu Dojo Bali is a well-known co-working place located near Echo Beach in Canggu.[23] Canggu's well-known status contributes significantly to Dojo Bali's popularity. Dojo Bali is synonymous with co-working Bali, where members cooperate and participate in activities. Dojo Bali co-working is a global and local community of individuals inspired to study and collaborate via the use of a shared workspace and high-speed internet connection.

Working in Dojo fosters an environment comfortable to productivity and provides ample opportunity for fresh air. As a result, digital nomads in Dojo gain experience networking and establishing businesses with other digital nomads. Dojo Bali is a two-story facility equipped with modern amenities such as six fiber optics, a private skype room, and an airconditioned meeting room. Additionally, a swimming pool and tropical garden serve as a backdrop for this Dojo Bali co-working area. Additionally, Dojo Bali features a canteen and café with a variety of meal options. Similar to Hubud, Dojo Bali also offers coliving. Accommodation supplied by Dojo Bali is located approximately five minutes from the Dojo Bali and provides a temporary home for digital nomads throughout their stay in Bali. Dojo Bali's accommodations have been built to be as pleasant as private houses.

Based on the characteristics of digital nomad tourism that already exist in Bali and the benefits anticipated by digital nomad employees, this new type of tourism can be established outside of Ubud and Canggu. Other regions in Bali have the potential to create nomadic tourism due of the simplicity with which this lifestyle may be supported. Particularly in areas that have not been developed previously.

\section{CONCLUSION}

Digital nomad tourism that develops in Bali is complete with coworking, good weather, easy access, internet access, a variety of tourist attractions, beautiful natural attractions, culture and friendly local community, amenities, the involvement of tourism institutions that support tourist destinations, security of destination. Those aspects are able to lead the comfort, friendly natural environment, existence of travel agency services, and existence of special events that have never been encountered in their origin country. Three elements in this model are digital nomad, online business opportunities and a good entrepreneurial spirit for managers and supporters becomes the important things to develop this new tourism.

There are three factors; entrepreneurship in the digital era, alternative business opportunity, and ease of doing business will help the community develop this kind of tourism. Moreover, community-based management in business improve the welfare of the community and ensure the community still employed to get monthly income even in the new normal conditions of the Covid 19 pandemic. In the pandemic era this community help many people to get income.

Indonesia government can copy the pattern of digital nomad lifestyle in Bali and implement it in another area in Indonesia to improve tourism in Indonesia so the economy can develop as alternative sector for Indonesia's people. The success of digital nomadic tourism in Bali can be encouraged as different tourism which can catch tourist to come and enjoy the beauty of Indonesia. The existence of nomad digital in Bali help developed many places like Ubud and Canggu. This is the new potential of tourism which can be developed further since there are many spaces not functionally improved in other areas in Indonesia.

\section{ACKNOWLEDGMENT}

We thank those who have helped the publication of this article. Especially for colleagues who have helped write and improve this article. Maybe next time we can work together again

\section{REFERENCES}

[1] UNWTO, "UNWTO Tourism Highlights," UNWTO, 2018.

[2] Faktanews, "Sektor Pariwisata Indonesia sebagai Kekuatan Ekonomi Utama Serta Penghasil Devisa Terbesar," htttp://fakta.news/berita/sektorpariwisata-indonesia, 2018.

[3] Anonimous. (2017) Trip Advisor 2017. [Online]. https://baligolive.com/articles/congratulationsbali-worlds-1-bestdestination-tripadvisor-2017

[4] Dinas Pariwisata Provinsi Bali (http://www.disparda.baliprov.go.id/id/Statistik4) 2018.

[5] Badan Pusat Statistik Provinsi Bali. (2019) Badan Pusat Statistik Provinsi Bal. [Online]. https://bali.bps.go.id/ statictable/2018/02/09/28/ jumlah-wisatawan-asing-ke-bali-dan-indonesia1969-2018.html

[6] G.I.Bhaskara and D.P. Sugiarti, "Enhancing Cultural Heritage Tourism Experience with Augmented Reality Technology in Bali," EJournal of Tourism, vol. 6, no. 1, pp. 102-118, 2019.

[7] R. M. Zulkarnaen, Z. Dewantara, dan Y. Prayogi H.Ritchi, "Pemanfaaatan Teknologi Informasi Dalam Upaya Peningkatan Aksesibilitas UKM 
(Desa Wisata) Kepada Pasar di Lokasi Wisata Pangandara dan Sekitarnya ," Jurnal Pengabdian Kepada Masyarakat, vol. 2, no. 1, 2018.

[8] I. N. D. Putra and A. S. Wiranatha I. A. Karisma, "The Effects of Search Engine Optimization on Marketing of Diving Companies," E-Journal of Tourism, vol. 6, no. 1 .

[9] Dyah Ikhsanti, "Siapa Digital Nomad dan Bagaimana Cara Menghasilkan Uang Jarak Jauh ?,"

htttps://www.aturduit.com/articles/penghasilandari-dunia-digital, 2017.

[10] R Novriandi, "Lima Keuntungan Jadi Pekerja Nomad," pp. https://www.kincir.com/chillax/jobeducation/5-keuntungan-jadi-pekerja-digitalnomad, 2017.

[11] T. Makimoto and D. Manners., Digital Nomads. Chichester: Wiley Publisher, 1997.

[12] MBO Patrners Inc., "A State Of Independence In America Research Brief Digital Nomadism: A Rising Trend," mbopartners.com, 2018.

[13] WYSE Travel Confederation. (2019) Digital nomads - the next darling of tourism destinations worldwide?

[Online]. https://www.wysetc.org/2018/08/digital-nomadsthe-next-darling-of- tourism-destinationsworldwide-2/

[14] S Koeswologito, "Bali and the rise od Digital Nomad: And Do You Make the Cut ?," Thrive Global, 2018.

[15] N. E. Wallen, and H. H. Hyun J. R. Fraenkel, How to design and evaluate research in education. New York: McGraw Hill, 2012.

[16] D. J Timothy, Tourism in Mongolia. In The Routledge Handbook of Tourism in Asia.: Routledge, 2016.

[17] Y Mahendradhata, "Proceed with caution: Potential challenges and risks of developing healthcare tourism in Indonesia," Global Public Health, vol. 14, no. 3, 2019.

[18] I. M. Budiasa, I.K. Suparta \& I.W.Nurjaya (2019, October)Implementation of Green Tourism Concept on Glamping Tourism in Bali In International Conference On Applied Science and Technology 2019-Social Sciences Track (iCASTSS 2019). Atlantis Press

[19] G.Tiberghien \& P. F.Xie, "The life cycle of authenticity: neo-nomadic tourism culture in Kazakhstan," Journal of Tourism and Cultural Change, 2018.

[20] N Leiper... Annals o Tourism Research. Vol. 17. Issue 3., "Tourist Attraction System," Annals o Tourism Research, vol. 17, no. 3, 1990.

[21] UNEP. (2010, January) http://www.unep.fr/scp/tourism/sustain/ ikarempacts/ economic/ negative.htm. [Online]. http://www.unep.fr/scp/tourism/sustain/

ikarempacts/ economic/ negative.htm

[22] Kadek Eni Marhaeni, I Wayan Putrana and I Gusti Agung Mirah Sanjiwani I Gusti Ketut Gede, "A Model of Community-Based Development in Digital Nomad Tourism in Intaran Village Bali," in Proceedings of the International Conference on Science and Technologyon Social Science (ICAST-SS 2020), 2020, pp. 382-386.

[23] Made Antara, Agung Cahyawan Wiranatha, Putu Sayorini Piartrini, Ida Bagus Gde Pujaastawa and I Gusti Ayu Oka Suryaw 